\title{
A Study of Internet Use in EFL Teaching and Learning in Northwest China
}

\author{
Chunqin Zhang ${ }^{1}$ \\ ${ }^{1}$ College of Humanities and Foreign Languages, Xi'an University of Science and Technology, China \\ Correspondence: Chunqin Zhang, College of Humanities and Foreign Languages, Xi' an University of Science and \\ Technology, Lintong, Xi’an 710600 Shanxi, China. E-mail: javalongbow@163.com
}

Received: November 4, 2012 Accepted: December 5, 2012 Online Published: January 28, 2013

doi:10.5539/ass.v9n2p48

URL: http://dx.doi.org/10.5539/ass.v9n2p48

\begin{abstract}
Internet has been researched and employed as an educational tool by teachers and researchers in many countries in recent years. This paper explores Internet use in EFL teaching and learning in universities in Northwest China. A quantitive research was conducted among college teachers and students. The result indicates that both teachers and students are not well prepared for the use of Internet in EFL teaching and learning. Based on the result, this paper presents three suggests: developing an EFL teaching and learning website; sharing the various English resources; cultivating teacher and learner autonomy.
\end{abstract}

Keywords: internet, English, website

\section{Introduction}

In the past several decades, EFL (English as a Foreign Language) teaching and learning has undergone two great changes. The first change is the shift from teacher-centered classroom to learner-centered classroom. In the time when teachers dominated the classroom, teachers seemed to be responsible for learners' achievement. So studies EFL learning focused on the revolution of teaching mothodologies. From Grammar Transtlation Mothed to Communicative Approach, studies on teaching methods have gone so far that they have to a great extent effectively motivated and guided learners in EFL learning. Then teachers and researchers realize that learners should also take the respnsiblity for their own language learning. Learners are expected to learn autonomously both within and outside of the classroom. The second change is the changing of the educational environment. In the $21^{\text {st }}$ century, new technologies are widely used in Education. From Computer Assisted Language Learning to Information and Communication Technology, teachers and researchers have been interested in the adoption of new technologies in EFL teaching and learning. The new technologies are claimed to provide greater freedom and conveniece for learners to learn in a flexible environment.

Internet, as one example of Computer Assisted Language Learning, is playing an important role in EFL learning and instruction. The use of Internet in language teaching and learning dates back to 1960s. And the first materials using Internet for language teaching appeared in the early 1990s. However, the internet with its abundant resources has not been widely used in language learning until the $21^{\text {st }}$ century. (Fidelman, 1997) It is argued that web-based teaching materials on the Internet serve as a platform to facilitate teaching and learning and provide new approaches for conducting classes and delivering course materials. (Ngai et al, 2007) Moreover, application of web-based activities and integration of technology in language instruction were found to have a positive effect on learners' attitudes and their motivation for learning a foreign language (Chen, 2004). On this ground, this paper makes an effort to investigate the use of Internet in EFL teaching and learning in Northwest China, and it will also explore the possible barriers hindering the internet use and propose corresponding solutions.

\section{Research on EFL Teaching and Learning in Northwest China}

\subsection{English Teaching and Learning Context}

The use of technology in classroom has been increasingly the object of study in recent years in China. However, despite all the effort made by researchers and teachers, the use of Internet is still in its infancy in Chinese higher education, especially in universities in Northwest China, where the economy is less developed. A variety of factors contribute to the reluctance in the use of Internet in English learning in higher educational institutions in Northwest China: computer access, time strains, individual computer skills and hardware issues, learner 
social-cultural backgrounds, pervious knowledge and learning experiences.

English learning in China is accorded with high attention. English courses, especially reading and listening, are compulsory courses for non-English majors. They are required to learn English for the first two years in college and to pass the national English examination called CET-4 (College English Test Band 4) and CET-6 (College English Test Band 6). High proficiency in English and the passing of CET-4 and CET-6 means the access to Bachelor's Degree and more opportunities of landing on a good job. However, English teaching and learning are somewhat restrained in the higher educational context in China. In conventional settings, language classes are "teacher-led, classroom-dependent and textbook-based" (Gu, 2002):Teachers and students share a textbook, teachers explain the language points to students, students take notes in a notebook and try to memorize them; Class hours are limited, on average, about 5-6 periods a week; language classes are quite large involving over 50 students. As a result, the long standing transmission mode of teaching oriented towards passing exams rather than developing communicatively competent language learners has produced generations of "deaf-and-dumb" graduates.

In recent years, universities in Northwest China are making effort to change the teaching and learning context through the adoption of technologies, mostly multimedia equipment, which has, to a certain degree, vitalized the conventional classroom. Learning technologies are considered as part of a learning context which encourages independence in learning, enhances deep learning approaches and desirable learning outcomes. However, the use of multimedia mainly involves PPT and CDROM, which, as is proved, has both advantages and disadvantages. Students may be attracted by the texts, graphics, sound and video in a short time, but they will soon realize that they are still learning passively as in a conventional classroom and this context brings inconvenience for the interaction between teachers and students. In this regard, teachers as well as students may feel frustrated and retreat to the conventional way of teaching and learning. And this frustration may hinder teachers' further adoption of new technologies.

\subsection{Research Methodology}

The research was carried out in the Northwest city in China, Xi'an. Xi'an city is a university intensive city, over ten major national universities locate here, among which five are key universities. In this research, 54 teachers and 350 students were randomly selected from ten universities as research subjects. Among them, 17 teachers and 223 students are male, while 37 teachers and 177 students are female. Quantitative research instrument is employed in this research, which involves a questionaire with 12 items. The 12 items are categorized into three factors: attitudes towards integration of Internet and English learning and access to computer and Internet; Internet use in language teaching and learning; knowledge of network technology.

All the items were of the five Likert scale type, composed of a statement to which respondents would indicate one of five responses: Strongly disagree, Disagree, Neither agree or disagree, Agree, or Strongly Agree. Each response was given a score from 5 (strongly agree) to 1 (strongly disagree). The average score was calculated. Thus an average score of 5 would mean that the subjects had strongly agreed with a statement; an average of 1 would mean that they had all strongly disagreed; if all subjects had been neither agree nor disagree with a statement, the average would be 3 . Since the subjects were not told that the numbers represent the scores of the responses, they were not sensitive to the numbers, which contributed to the reliability and validity of their responses.

This research was conducted online and 389 effective questionnaire papers were collected. The answers to the questionnaire statements were keyed into and stored in the statistical package SPSS (11.5) in the computer. A few missing or unclear responses were offered a neutral value 3 , which would not change the mean of the item and affect further analysis. The calculation and analysis of the data took two steps: first, calculating the mean of the scores for each item. Second, to further ensure the reliability of the questionnaire and the research findings, item-total correlation were examined.

\subsection{Finding}

Table 1. Findings of attitudes towards Internet use in EFL teaching /learning and access to internet

\begin{tabular}{lll}
\hline variables & Mean & S.D. \\
\hline Internet use could help enhance the quality of English teaching /learning. & 4.23 & 0.871 \\
Internet will help students find English resources in the information age. & 4.09 & 0.878 \\
Internet will benefit English reading, writing, listening, speaking and translation. & 4.27 & 0.854 \\
It is easy to have access to computers and Internet in our university. & 3.82 & 0.910 \\
\hline
\end{tabular}


The first three statements are about the attitudes of teachers and students towards the use of Internet in English teaching and learning. The data $(M>4)$ indicates that the participants responded positively about these statements. Statement 4 is about the participants' access to computers and Internet in universities. The research result $(\mathrm{M}=3.82)$ shows that computers and Internet are available in universities but not highly accessible.

Table 2. Findings of Internet use in EFL teaching/learning

\begin{tabular}{lll}
\hline \multicolumn{1}{c}{ variables } & Mean & S.D. \\
\hline Internet has already been integrated into English teaching /learning in classroom. & 1.9 & 0.823 \\
Internet has already been integrated into English teaching/learning outside of classroom. & 2.2 & 0.933 \\
I often use Internet as an electronic dictionary. & 2.6 & 1.152 \\
I often use Internet as a source of English materials. & 3.26 & 0.962
\end{tabular}

The four statements in Table 2 concern the use of Internet in English learning in and outside of classroom by both teachers and students. The data shows that the actual use of Internet in language learning is not satisfactory. Internet is lest used in language classroom $(\mathrm{M}=1.9)$, while its use outside of classroom is below the average $(\mathrm{M}=2.2)$. Less than half of the teachers and students consult the electronic dictionary $(\mathrm{M}=2.6)$. The use of Internet as a resource of English materials is relatively more popular among teachers and students $(\mathrm{M}=3.26)$.

Table 3. Findings of knowledge about network technology

\begin{tabular}{lll}
\hline \multicolumn{1}{c}{ variables } & Mean & S.D. \\
\hline I know how to use Internet in my English teaching/learning. & 3.21 & 1.012 \\
I know how to develop website for English teaching/learning. & 1.25 & 0.965 \\
I know about computer software and hardware. & 1.91 & 0.971 \\
I know how to use blogs, email and QQ to exchange information. & 4.09 & 0.874 \\
\hline
\end{tabular}

The four statements in Table 3 are designed to research participants' knowledge about network technology. The results of statement 2 and statement 3 ( $M=1.25$ and $\mathrm{M}=1.91$ respectively) are negative, from which we can see that only a quite small number of participants have relevent computer knowledge. Teachers and students know much about the use of blogs, email and QQ in information exchange $(\mathrm{M}=4.09)$, while they have less knowledge of the use of Internet in English teaching and learning $(\mathrm{M}=3.21)$.

\section{Discussion and Suggestion}

According to findings stated above, the results of the research can be concluded as the following four points:1) teachers and students show positive attitude towards the use of Internet in English teaching and learning. 2) they have certain knowledge about Internet use in English teaching and learning and daily communication. 3) they have not so far well integrated Internet into English teaching and learning. 4) the knowledge of teachers and students about computer and network technology is quite limited. To better strength their positive attitude and knoweledge about Internet use in English teaching and learning and overcome their problems, three suggestions are proposed in this paper: teachers and students are supposed to make a joint effort to develop an English teaching and learning website; they are expected to get aquainted with the abundant resources on the Internet and share them with each other; they should be independent of the conventional teaching and learning method by cultivating teacher autonomy and learner autonomy.

\subsection{Developing a Website for English Teaching and Learning}

The establishment of Internet as a formal educational tool is not easily realized in terms of the EFLteaching and learning context in Northest China. The conventional mode of teaching has been long established, and it takes both awareness and courage to change it. The inadequate financial support from the government makes it impossible for a university to set up classrooms equipped with advanced technology. In this case, an English website can be established by the joint effort of both teachers and students since teachers are not more acquainted with computers and Internet than students. Through this website, teachers and students can share and exchange information and experiences about English learning. In this way, communication between teachers and students and among students will increase. More English websites will be introduced and more English learning materials will be shared and there will be more chances for students to practice language skills, reading, writing, listening and speaking, since there is no time limit in this virtual classroom. 


\subsection{Sharing Resources Available on the Internet}

One important factor leading to teachers' and learners' failing to integrate Internet into English teaching and learning is that both teachers and learners are not familiar with the resources available on the Internet. Finnemann (1996) outlines the most common uses of the Internet for language teaching by dividing the resources available on the Internet into two broad categories: teacher-centered resources and student-centered resources. Teacher-centered resources include foreign language magazines and newspapers and reference books. While a great many of student-centered resources can also be found on the Internet (ames, 2001). Students can access a variety of websites to research the countries and cultures that speak English. They can also practice grammar and vocabulary skills with interactive language programs and develop listening and speaking skills by consulting interactive web pages. The amount of information teachers and students can find on the Internet tends to be unlimited. However, university teachers and learners in Norwest China have not realized the importance of the resources and made their efforts to find and use them in their English teaching and learnig. Therefore, teachers and students should enrich the established website with related resources and share them with each other.

\subsection{Cultivating Teacher Autonomy and Learner Autonomy}

Both teachers and students depend much on the conventional way of teaching and learning. However, with the changing of the teaching and learning environment, teachers should cultivate teacher autonomy and learner autonomy. They need to learn the benefits that Internet has brought. Teachers should act as the motivator of the whole learning process, who facilitates intellectual group discussion. They must also reflect critically on the context of learning mediated by technology, teaching methods, students, and their own computer literacy. As Zepp (2005) points out, teachers should combine the goals of education with effective use of Internet. Pramela (2006) emphasizes on the importance of feedback in teaching and learning in the electronic media because helpful feedback given to learners means creating social presence which is crucial in the virtual mode of learning. This is because technology cannot replace good teaching but it can enhance it. Teachers should take the responsibility to explore the digital world, and acquaint students with it. In this case, they are able to cultivate learner automomy. And learner autonomy is the ultimate educational goal, expecially in the digital society.

\section{Conclusion}

With the increasing access to computers and Internet, teachers as well as students will be more acquainted with the integration of Internet with EFL teaching and learning in Chinese educational settings. However, the conventional EFL classroom still dominates language learning field, and Internet is still a supplement to the formal classroom. Therefore, teachers will have to face up to the challenge of equipping themselves with computer literacy and Internet in the new education-with-technology era. New generations of students who grow up as a net generation should also facilitate the process of English learning on the Internet.

\section{References}

Ames, Y. (2001). Foreign languages study on the Internet. Retrieved from hattp:// www.lesley.edu/alumni/ames.html

Chen, P. (2004). EFL student learning style preferences and attitudes toward technology-integrated instruction Ph.D. Dissertation, University of South DakotaDAI-A 64/08, 2813.

Claudia et al. (2004). Factors influencing the adoption of the Internet as a teaching tool at foreign language schools. Computers and Education, 42, 353-374. http://dx.doi.org/10.1016/j.compedu.2003.08.007

David, G., \& Miller, L. (2011). Managing self-access language learning: Principles and practice. System, 39, 78-89. http://dx.doi.org/10.1016/j.system.2011.01.010

Ehsan, R. (2011). On the effectiveness of using web-and pint-based materials in teaching grammar to Iranian EFL $\begin{array}{llllll}\text { learners. Procedia Social and Behavioral Sciences, } & \text { 15, 376-381. }\end{array}$ http://dx.doi.org/10.1016/j.sbspro.2011.03.105

Fidelman, C. G. (1997). The third annual Internet use survey of language professionals. Agora Newsletter, 3(1), $1-15$.

Finnermann, M. D. (1996). The world wide web and foreign language teaching. ERIC/CLLNewsBulletin, 20(1), $1-10$.

Gu, Y. (2002). From Classroom to Distance Internet. Beiwai Online Newsletter. Retrieved from http://www. Beiwaionline.com/newsletter/newsletter2/zhuanjialunta.htm 
Ngai, E. W. T., Poon, J. K. L., \& Chan, Y. H. C. (2007). Empirical examination of the adoption of WebCT using TAM. Computers and Education, 48(2), 250-267. http://dx.doi.org/10.1016/j.compedu.2004.11.007

Pramela, K. (2006). Factors affecting the online delivery of English Language courses in a virtual learning environment. Unpublished $\mathrm{PhD}$ thesis.

Zepp, R. A. (2005). Teachers perceptions on the roles on educational technology. Educational Technology \& Society, 8(2), 102-106. 